\title{
Physiological and agronomic performance of common bean treated with multifunctional microorganisms
}

\author{
Cássia Cristina Rezende ${ }^{1 *}\left({ }^{-}\right.$, Adriano Stephan Nascente ${ }^{2} \oplus$, Mariana Aguiar Silva ${ }^{1}(\mathbb{C}$,

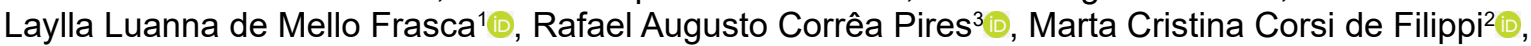 \\ Anna Cristina Lanna ${ }^{2}$, José Francisco Arruda e Silva²

\footnotetext{
1 Universidade Federal de Goiás, Goiânia, GO, Brasil. E-mail: cassiacristinarezende@hotmail.com; marianaaguiar23@hotmail.com; layllafrasca@gmail.com

2 Embrapa Arroz e Feijão, Goiânia, GO, Brasil. E-mail: adriano.nascente@embrapa.br; cristina.filippi@embrapa.br; anna.lanna@embrapa.br; j.chikosilva@hotmail.com

${ }^{3}$ Centro Universitário de Goiás, Goiânia, GO, Brasil. E-mail: rafaelaugusto.correa@gmail.com
}

ABSTRACT: Multifunctional microorganisms (MM) are able of colonizing root system and shoots and then, provide beneficial effects to the plants. Thus, the objective of this study was test whether multifunctional microorganisms affect gas exchange, macronutrient content, yield components and bean grain yield. A completely randomized design with twenty-six treatments and three replications was used under controlled conditions. Treatments consisted of the application of MM and its combinations in pairs, with nine rhizobacteria isolates BRM 32109, BRM 32110 and 1301 (Bacillus sp.), BRM 32111 and BRM 32112 (Pseudomonas sp.), BRM 32113 (Burkholderia sp.), BRM 32114 (Serratia sp.), 1381 (Azospirillum sp.) and Ab-V5 (Azospirillum brasiliense), an edaphic fungal isolate T-26 (Trichoderma koningiopsis), and a control (without MM). The isolates Ab-V5 and BRM 32112, in addition to the combinations BRM 32114 + T-26, $1301+$ BRM 32110 and BRM $32114+$ BRM 32110 were the highlights treatments, since they provided increases in gas exchange, in the content of macronutrients and in the agronomic performance.

Key words: bioagents; gas exchange; grain yield; nutrients; Phaseolus vulgaris

\section{Desempenho fisiológico e agronômico do feijão-comum tratado com microrganismos}

RESUMO: Microrganismos multifuncionais (MM) são capazes de colonizar o sistema radicular e a parte aérea das plantas e proporcionar efeitos benéficos ao sistema. Assim, o objetivo deste trabalho foi testar se os microrganismos multifuncionais afetam as trocas gasosas, o teor de macronutrientes, os componentes do rendimento e o rendimento de grãos do feijãocomum. $O$ delineamento inteiramente casualizado com vinte e seis tratamentos e três repetições foi utilizado em condições controladas. Os tratamentos consistiram na aplicação de MM e em combinações aos pares, com nove isolados de rizobactérias BRM 32109, BRM 32110 e 1301 (Bacillus sp.), BRM 32111 e BRM 32112 (Pseudomonas sp.), BRM 32113 (Burkholderia sp.), BRM 32114 (Serratia sp.), 1381 (Azospirillum sp.) e Ab-V5 (Azospirillum brasiliense), um isolado fúngico edáfico T-26 (Trichoderma koningiopsis) e um controle (sem MM). Os isolados Ab-V5 e BRM 32112, além das combinações BRM 32114 + T-26, 1301 + BRM 32110 e BRM 32114 + BRM 32110 foram os tratamentos de destaque, pois proporcionaram aumentos nas trocas gasosas, no teor de macronutrientes e no desempenho agronômico.

Palavras-chave: bioagentes; trocas gasosas; produtividade; nutrientes; Phaseolus vulgaris

\footnotetext{
*Cássia Cristina Rezende - E-mail: cassiacristinarezende@hotmail.com (Corresponding author)

Associate Editor: Mário de Andrade Lira Júnior
} 


\section{Introduction}

Common bean (Phaseolus vulgaris L.) is one of the most important legumes for food consumption in Brazil and worldwide (Carbonell et al., 2019; Ganascini et al., 2019). Common bean grains is considered a source of basic protein for direct consumption, low cost, excellent source of fiber, iron and amino acids (Li et al., 2017). Brazil is the world's largest producer of this legume with a cultivated area of 2,926.2 thousand ha, productivity of $1,074 \mathrm{~kg} \mathrm{ha}^{-1}$ and production of 3,144.2 thousand tons (Conab, 2021), in addition to being cultivated in almost all Brazilian states (Carbonell et al., 2019).

Smallholder's farms dominate the Brazilian production of common beans (about 67\%), but there is a tendency to increase the participation of medium and large farmers, mainly in the Cerrado region (irrigated winter cultivation) (Ganascini et al., 2019). According to Carbonell et al. (2019), winter cultivation is characterized by the intensive use of synthetic inputs, like chemical fertilizers that provide significant increases in grain yield, however, it also increases production costs.

In view of the serious consequences of the intensive use of agricultural inputs has caused to the agro-ecosystems, such as air and water pollution, soil contamination and human health problems, the idea of environmental conservation and the rational use of its resources has become increasingly relevant (Ekin, 2019). As an example, there are the specific interactions between plants and multifunctional microorganisms, which have a positive impact on the ecosystems, such as nitrogen fixation, phosphate solubilization and microbiolization, production of phytohormones, biofilm, siderophores, biological control and maintenance of the food chain and biogeochemical cycles (Braga et al., 2016).

In this context, rhizobacteria, able of rapidly colonize root system of plants, represent strategic organisms in the soilplant system because in addition to preventing the invasion of pathogens through the production of secondary metabolites (Oliveira et al., 2016) also help the plants to growth and develop better (Ahemad \& Kibret, 2014). Among the positive effects of these bacteria there are: $N_{2}$ fixation (Damam et al., 2016), production of phytohormones (Sureshbabu et al., 2016), increased phosphate solubilization (Paiter et al., 2019), stimulus to the greater root development of plants (Aquino et al., 2018), increased absorption of water and nutrients (Sureshbabu et al., 2016), control of phytopathogens (Singh et al., 2019), among others that result in greater plant development and greater grain yield in contrast to nontreated plants (Ekin, 2019).

In addition to rhizobacteria, the soil fungus, Trichoderma spp., also plays a major role in plant growth (Aquino et al., 2018). Its effect has been related to the protection of plants against primary and secondary rhizosphere pathogens, production of plant growth hormones, increased absorption and translocation of mineral nutrients, in addition to increased solubility and availability of many nutrients (Montesinos et al., 2019).
Additionally, the co-inoculation with rhizobacteria has been proposed as a technology able of enhancing the promotion of growth in plants and, consequently, benefiting the $\mathrm{N}_{2}$ fixation process and stimulating the increase in the absorption of water and nutrients, compared to the application of individual isolates (Korir et al., 2017). However, despite of the potential for the use of multifunctional microorganisms in agricultural crops, mainly in co-inoculation, there are still few works published in the crop of common bean.

Thus, we tested whether multifunctional microorganisms affect gas exchange, macronutrient content, yield components and grain yield of common bean plants.

\section{Materials and Methods}

\section{Characterization of the environment}

The experiment was conducted in a greenhouse, at the headquarters of Embrapa Rice and Bean, Santo Antônio de Goiás, GO. Soil from the arable layer $(0.00-0.20 \mathrm{~m})$ of a dystrophic Oxisol, medium texture, was used. The chemical characteristics of the soil were determined with the following results $\mathrm{pH}\left(\mathrm{H}_{2} \mathrm{O}\right)=5.6 ; \mathrm{Ca}^{2}+=28.4 \mathrm{mmol}_{\mathrm{c}} \mathrm{dm}^{3} ; \mathrm{Mg}^{2+}=12.5$ $\mathrm{mmol} \mathrm{dm}^{-}{ }^{3} ; \mathrm{H}+\mathrm{Al}^{3+}=28 \mathrm{mmol}_{\mathrm{cm}}{ }^{3} ; \mathrm{P}=11 \mathrm{mg} \mathrm{dm}{ }^{3} ; \mathrm{K}+=$ $218 \mathrm{mg} \mathrm{dm}^{-} ; \mathrm{Cu}^{2+}=0.8 \mathrm{mg} \mathrm{dm}^{-}{ }^{3} ; \mathrm{Zn}^{2+}=4.0 \mathrm{mg} \mathrm{dm}^{-}{ }^{3} ; \mathrm{Fe}^{3+}=7.3$ $\mathrm{mg} \mathrm{dm}{ }^{3} ; \mathrm{Mn}^{2+}=18 \mathrm{mg} \mathrm{dm}^{-3}$ and organic matter $=37.7 \mathrm{~g} \mathrm{~kg}^{-1}$.

Three weeks before the sowing of common bean, 78 pots with a capacity of $7 \mathrm{~kg}$ were completely filled with soil and fertilized with $10 \mathrm{~g}$ of NPK, formulation 5-30-15. During the entire conduct of the experiment, soil moisture was monitored daily, and kept close to field capacity conditions.

\section{Experimental design and treatments}

A completely randomized design with 26 treatments and three replications was used. Treatments consisted of the application of microorganisms and their combinations in pairs in common bean, with nine rhizobacteria isolates and one fungus isolated from soil (Table 1). Microorganisms were applied at three times in the crop, microbiolization of the seeds and sprayed of microorganisms solution at 7 (soil) and 21 (plants) days. In the control treatment, water was used both for microbiolization, as well as spraying at 7 and 21 days.

The main characteristics of the rhizobacteria isolates BRM 32109 (Bacillus sp.), BRM 32110 (Bacillus thunringiensis), BRM 32111 (Pseudomonas fluorescens), BRM 32112 (Pseudomonas sp.), BRM 32113 (Burkholderia pyrrocinia), BRM 32114 (Serratia sp.), 1301 (Bacillus sp.), 1381 (Azospirillum sp.), AbV5 (Azospirillum brasilense) and the fungus T-26 (Trichoderma koningiopsis) are described in Table 2. The microorganisms used are stored and preserved in the Multifunctional Microorganisms collection of Embrapa Rice and Bean.

\section{Microbiolization of seeds}

Each bacterium was grown in solid medium (nutrient agar), suspensions with the bacteria were prepared in liquid medium 523 (nutrient broth) (Kado \& Heskett, 1970), in a shaking incubator, for 24 hours at $28{ }^{\circ} \mathrm{C}$. The suspension concentration 
Table 1. Multifunctional microorganisms, isolated or combined, used during the cultivation of common bean, cultivar BRS FC 402.

\begin{tabular}{clcc}
\hline Treatments & \multicolumn{1}{c}{ Microorganisms } & Treatments & Microorganisms \\
\hline 1 & BRM 32109 (Bacillus sp.) & 14 & $1301+32114$ \\
2 & BRM 32110 (Bacillus thunringiensis) & 15 & $1381+32114$ \\
3 & BRM 32111 (Pseudomonas fluorescens) & 16 & $1381+1301$ \\
4 & BRM 32112 (Pseudomonas sp.) & 17 & $32110+$ Ab-V5 \\
5 & BRM 32113 (Burkholderia pyrrocinia) & 18 & $32114+\mathrm{Ab}-\mathrm{V} 5$ \\
6 & BRM 32114 (Serratia sp.) & 19 & $1301+\mathrm{Ab}-\mathrm{V} 5$ \\
7 & $\mathrm{~T}-26$ (Trichoderma koningiopsis) & 20 & $1381+\mathrm{Ab}-\mathrm{V} 5$ \\
8 & Ab-V5 (Azospirillum brasilense) & 21 & Ab-V5+T-26 \\
9 & 1381 (Azospirillum sp.) & 22 & $32110+\mathrm{T}-26$ \\
10 & 1301 (Bacillus sp.) & 23 & $32114+\mathrm{T}-26$ \\
11 & $32114+32110$ & 24 & $1301+\mathrm{T}-26$ \\
13 & $1301+32110$ & 26 & $1381+\mathrm{T}-26$ \\
\end{tabular}

Table 2. Collection code, geographical origin, biochemical characteristics and taxonomic classification of the nine rhizobacteria isolates used in this study.

\begin{tabular}{|c|c|c|c|c|c|c|c|c|}
\hline \multicolumn{9}{|c|}{ BiochemicalD } \\
\hline Code $^{A}$ & Origin $^{B}$ & Colore & $\mathrm{AIA}^{\mathrm{F}}$ & Cel. $^{G}$ & Phos $^{H}$ & Sid" & Biofilm ${ }^{J}$ & Taxonomic $^{\mathrm{E}}$ \\
\hline BRM 32109 & GO/Brazil & White & - & + & + & + & + & Bacillus sp. \\
\hline BRM 32110 & PA/Brazil & White & - & + & + & - & + & Bacillus thunringiensis \\
\hline BRM 32111 & PA/Brazil & Yellow & - & + & + & + & + & Pseudomonas fluorescens \\
\hline BRM 32112 & GO/Brazil & Yellow & - & + & + & + & + & Pseudomonas sp. \\
\hline BRM 32113 & PA/Brazil & Pink & + & + & - & + & + & Burkholderia pyrroiynia \\
\hline BRM 32114 & PA/Brazil & Pink & + & + & + & + & + & Serratia sp. \\
\hline $\mathrm{Ab}-\mathrm{V} 5$ & PR/Brazil & Yellow & + & - & - & + & + & Azospirillum brasilense \\
\hline 1381 & & White & + & - & - & - & - & Azospirillum sp. \\
\hline 1301 & & White & - & - & + & - & - & Bacillus sp. \\
\hline
\end{tabular}

${ }^{A}$ Numeric code of rhizobacteria and fungus isolates in the Embrapa Rice and Bean collection of Multifunctional Microorganisms.

${ }^{B}$ Geographic source of each isolate.

$C, D, E$ Colony color, biochemical characterization and taxonomic classification of each isolate, described by Nascente et al. (2017).

FProducer of indolacetic acid, Gproducer of cellulase, Hproducer of phosphatase, Iproducer of siderophores, JProducer of biofilm. The methodology is described in Nascente et al. (2017).

of each bacterium was adjusted in a spectrophotometer to A540 $=0.5$, which corresponds to $1 \times 10^{8}$ colony-forming units (CFU) per $\mathrm{mL}$. The Trichoderma koningiopsis was grown in PDA culture medium, then multiplied in rice grain substrate and the suspension concentration corresponds to $1 \times 10^{8} \mathrm{ml}^{-1}$ of conidia. The seeds of common bean were immersed in each suspension of microorganisms, and the seeds of the control treatment were immersed in distilled water, for a period of 2 hours under constant agitation at 25ㅇ. .

Watering and spraying were carried out with the suspensions of microorganisms in the same concentrations used to microbiolize the seeds. Thus, at 7 days after sowing (DAS), the soil was watered with $100 \mathrm{ml}$ of suspension in each treatment and at 21 DAS the plants were sprayed with $30 \mathrm{ml}$ of suspension for each treatment, following the methodology of Silva et al. (2020). The plants were sprayed using a manual sprayer with pressure supplied by a $\mathrm{CO}_{2}$ pressure source and a conical nozzle (TX-VS2).

\section{Management of common bean plants}

Ten common bean seeds cultivar BRS FC 402 were sown per pot. Ten days after germination, the plants were thinned, leaving three plants per pot. Cultural practices were carried out according to the recommendations and needs of the crop.

\section{Assessments}

Gas exchange measurements: photosynthetic rate $(\mu \mathrm{mol}$

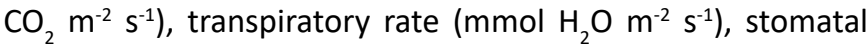

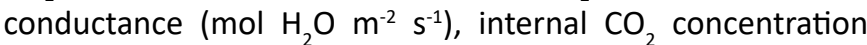
$(\mathrm{vpm})$ and leaf temperature $(\mathrm{O} \mathrm{C})$ were determined in common bean plants at 37 DAS (beginning of flowering), using a portable gas meter in the IRGA infrared region (LCpro +, ADC BioScientific), between 08:00 and 10:00 am. The readings were taken in the central third of the first completely expanded leave (from top to bottom). The equipment was regulated to use concentrations of $370-400 \mathrm{~mol} \mathrm{~mol}^{-1} \mathrm{CO}_{2^{\prime}}$ and 1200 $\mu \mathrm{mol}$ [quanta] $\mathrm{m}^{-2} \mathrm{~s}^{-1}$ of photosynthetically active photon flux density (DFFFA). The minimum equilibrium time established for the readings was 2 minutes.

Yield components and grain yield: harvesting was carried out when common bean plants reached physiological maturity, 83 DAS. Thus, the number of pods per pot, the number of grains per pod was counted and the mass of 100 grains and grain yield were determined. The values obtained were corrected for $13 \%$ humidity. These determinations were made in each per pot.

Nutrient content: after drying and weighing the dry biomass of the shoots and roots, representative aliquots were removed for grinding and determination of the levels of macronutrients $\mathrm{N}, \mathrm{P}$ and $\mathrm{K}$. 


\section{Statistical analysis}

It was determined normality of errors (Shapiro-Wilk test) and homogeneity of variance (Bartlett test) of the data. Then, the data were subjected to analysis of variance and, when significance was detected, the means were compared by the LSD test ( $p \leq 0.05)$. The SISVAR statistical package was used to process these data.

Additionally, a multivariate principal component analysis (PCA) was performed to describe the correlation between response variables (gas exchange, accumulation of nutrients in the shoots and roots, yield components and grain yield) and isolated and combined microorganisms. The main components (PCs) were loaded with response variables when the correlation test produced $r \geq 0.50$. The first five PCs responsible for $68.2 \%$ of the data variation were maintained. Biplots (two-dimensional graph) using these five PCs that correlate isolated and combined microorganisms and response variables were built with the "FactoExtra" package on the R platform.

\section{Results and Discussion}

\section{Gas exchange evaluation}

The effect of inoculation on common bean plants on photosynthesis $(A)$, transpiration (E), stomatal conductance (gs), internal $\mathrm{CO}_{2}$ concentration $(\mathrm{Ci})$ and leaf temperature (Tleaf) is shown in Figure 1.
The increase in $E$ ( $16.5 \%$ on average) and gs $(25.0 \%$ on average) in common bean plants inoculated with Ab-V5 ( $E$ and gs); and the combinations BRM $32114+\mathrm{Ab}-\mathrm{V} 5$ ( $E$ and gs), $1381+1301$ (gs) and $1301+\mathrm{T}-26$ (E) indicate that there was a greater flow of water and nutrients from the soil to the plant, since the supply water for the crop was abundant (Figure 1). This is advantageous since the higher nutrient content within the plant culminates in a more adequate metabolism and, consequently, accumulation of photoassimilates and growth gain.

According to Silva et al. (2017), a higher transpiratory rate is attributed to a greater stomatal opening, which in turn can be induced by multifunctional microorganisms. On the other hand, greater stomatal opening decreases stomatal resistance to $\mathrm{CO}_{2}$ diffusion, favoring its mesophilic conductance and, consequently, the production of photoassimilates. Although no difference in A was observed between inoculated and noninoculated plants, the photosynthetic rate of common bean plants is considered high, with emphasis on plants inoculated with Ab-V5, BRM 32113 and the combinations $1301+\mathrm{T}-26$ and $1301+$ BRM 32110 (Figure 1A).

Changes in the intercellular concentration of $\mathrm{CO}_{2}(\mathrm{Ci})$, found in common bean plants inoculated with the combinations $\mathrm{Ab}-\mathrm{V} 5+\mathrm{T}-26,1301+\mathrm{Ab}-\mathrm{V} 5, \mathrm{BRM} 32110+\mathrm{Ab}-\mathrm{V} 5$ and BRM $32114+\mathrm{T}-26$ (Figure 1E), suggest that there may have been an increase in Rubisco's carboxylation activity by regulating
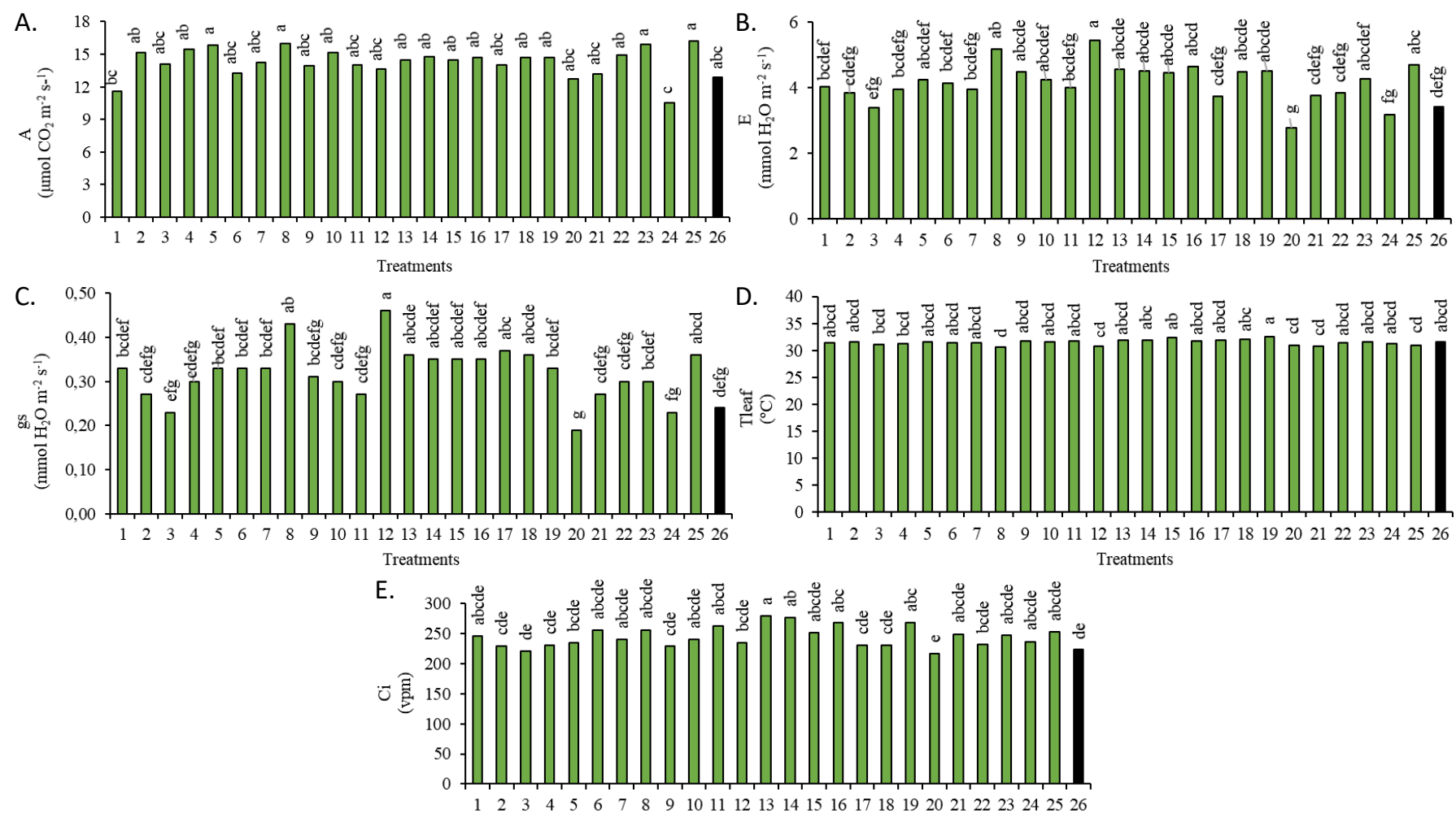

Treatments

* Treatments followed by the same letter in columns do not differ from each other by the LSD test ( $\mathrm{p} \geq 0.05)$. ** Treatments: (1) BRM 32109; (2) BRM 32110; (3) BRM 32111; (4) BRM 32112; (5) BRM 32113; (6) BRM 32114; (7) T-26; (8) Ab-V5; (9) 1381; (10) 1301; (11) BRM 32114 + BRM 32110; (12) BRM 32114 + Ab-V5; (13) BRM 32114 + T-26; (14) BRM 32110 + Ab-V5; (15) BRM 32110 + T-26; (16) Ab-V5 + T-26; (17) 1381 + 1301; (18) 1381 + Ab-V5; (19) $1301+$ Ab-V5; (20) 1381 + BRM 32114; (21) 1301 + BRM 32114; (22) 1381 + BRM 32110; (23) $1301+$ BRM 32110; (24) $1381+\mathrm{T}-26$; (25) $1301+\mathrm{T}-26$; (26) control (without microorganism).

Figure 1. (A) Photosynthesis; (B) Transpiration; (C) Stomatal conductance; (D) Leaf temperature and (E) Internal CO2 concentration in common bean plants treated with multifunctional microorganisms, isolated or in combination. 
the stomatal opening that favors the fixation of mesophilic $\mathrm{CO}_{2}$ (Shi et al., 2010). These benefits acquired with the use of multifunctional microorganisms can result in greater production of photoassimilates, which can be allocated to heterotrophic organs of common bean plants to sustain growth or be converted into reserve products or have been exuded by the roots and used by the rhizobacteria themselves. In upland rice, Nascente et al. (2017) found values significantly higher than the control treatment for the variables photosynthesis, transpiration and stomatal conductance, while there was no statistical difference for internal $\mathrm{CO}_{2}$ concentration and leaf temperature.

\section{Macronutrients in shoots and roots}

Common bean plants treated with isolates BRM 32112, 1381, BRM 32110, BRM 32114, BRM 32109, BRM 32111, AbV5, BRM 32113, T-26 and 1301, in addition to the combinations BRM 32114 + T-26, 1301 + BRM 32114, 1301 + Ab-V5, 1381 +1301, BRM $32110+$ T-26, BRM 32114 + BRM 32110 and 1301 + BRM 32110 presented the highest levels of $N$ in their shoots. The average increase was around $3.70 \%$ (Figure $2 \mathrm{~A}$ ).

In relation to macronutrient $P$, common bean plants treated with isolates BRM 32111, BRM 32112, BRM 32114, 1381, BRM 32110 and $A b-V 5$ and with the combination BRM $32114+B R M$ 32110 , showed significantly higher levels compared to control plants (Figure 2B). The average increase was of the order of
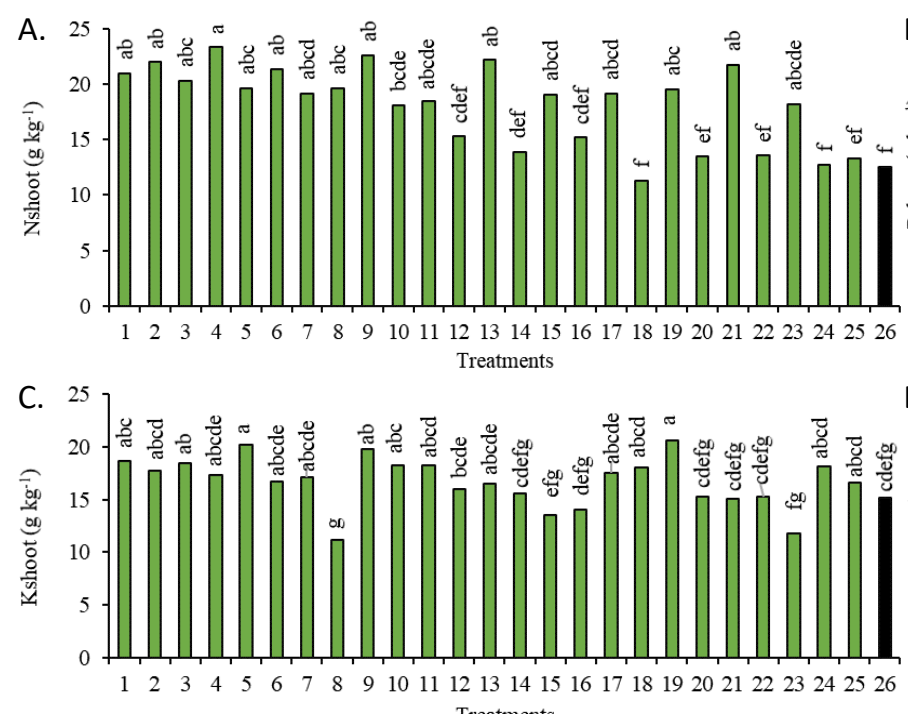
Treatments
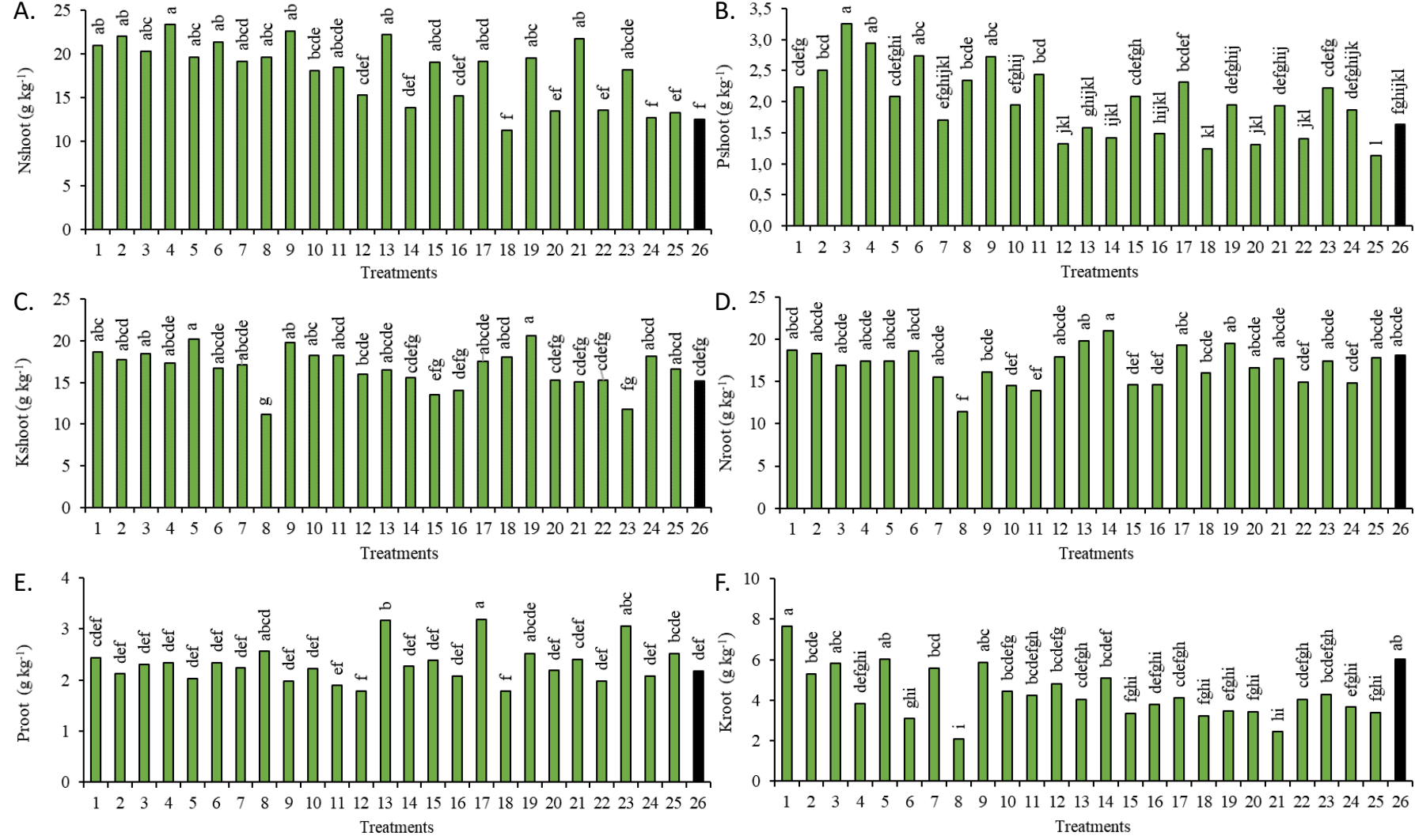

9.23\%. As for macronutrient $K$, common bean plants treated with the BRM $1301+A b-V 5$ combination and the BRM 32113 and 1301 isolates showed significantly higher levels (11.02\%) when compared to the control plants (Figure 2C). Regarding the levels of macronutrients in the roots of common bean plants, the levels of $\mathrm{N}$ and $\mathrm{K}$ were similar between treatments; while the $\mathrm{P}$ content was significantly higher in common bean plants treated with the combinations $1381+1301$, BRM $32114+\mathrm{T}-26$ and $1301+$ BRM 32110, compared to control plants (Figures 2D, 2E and 2F). The average increase in the $P$ content was around $14.68 \%$.

Multifunctional microorganisms can benefit plants through their ability to solubilize some nutrients in the soil solution and, thus, make them available to the plant to increase the growth rate (Chaudhary \& Sindhu, 2016). As observed in the present study, multifunctional microorganisms induced the accumulation of $\mathrm{N}, \mathrm{P}, \mathrm{K}$ in the shoots and $\mathrm{K}$ in the roots, positively influencing the growth of common bean plants. These results may be related, since the transpiration of the plant is fundamental for the absorption of water and mineral nutrients from the soil. The results show that the multifunctional microorganisms Ab-V5, BRM $32114+\mathrm{Ab}-$ V5 and $1301+T-26$ provided increases in transpiration of common bean plants.

Regarding $\mathrm{P}$, our results corroborate those of Braga Júnior et al. (2017), where several rhizobacteria tested,

* Treatments followed by the same letter in columns do not differ from each other by the LSD test ( $p \geq 0.05)$. ** Treatments: (1) BRM 32109; (2) BRM 32110; (3) BRM 32111; (4) BRM 32112; (5) BRM 32113; (6) BRM 32114; (7) T-26; (8) Ab-V5; (9) 1381; (10) 1301; (11) 32114 + 32110; (12) 32114 + Ab-V5; (13) 32114 + T-26; (14) 32110 + Ab-V5; (15) 32110 + T-26; (16) Ab-V5 + T-26; (17) $1381+1301 ;$ (18) $1381+$ Ab-V5; (19) $1301+$ Ab-V5; (20) $1381+32114 ;(21) 1301+32114 ;(22) 1381+32110 ;(23) 1301+32110 ;(24) 1381+T-26 ;(25) 1301$ $+\mathrm{T}-26$; (26) control (without microorganism).

Figure 2. (A) Nitrogen (shoot); (B) Phosphorus (shoot); (C) Potassium (shoot) and (D) Nitrogen (root); (E) Phosphorus (root); (F) Potassium (root) in common bean plants treated with multifunctional microorganisms, isolated or in combination. 
alone, provided higher phosphorus content in the shoots of inoculated plants than in uninoculated plants, both under natural phosphate fertilization and without using fertilizer. Therefore, the isolates BRM 32110, BRM 32111, BRM 32112 and BRM 32114, in addition to the combinations, BRM 32114 + BRM 32110, 1301 + BRM 32110 and BRM 32114 + $\mathrm{T}-26$ favored the solubilization of $\mathrm{P}$ in the soil solution and, consequently, accumulation of $P$ in the shoots and root of common bean plants. This can be explained due to the ability of these microorganisms to solubilize and mineralize inorganic phosphorus through organic acids, release of $\mathrm{H}^{+}$protons, aid of ATPases and production of chelators.

In addition, these microorganisms can favor the increase in the accumulation of nutrients in plants, promoting root development, which allows greater access and absorption of nutrients and improving the absorption mechanisms (Ahemad \& Kibret, 2014). Isolates 1381 and BRM 32113 and the combination $1301+\mathrm{Ab}-\mathrm{V} 5$ provided the highest $\mathrm{K}$ accumulation in the shoots. This suggests that the high accumulation of $\mathrm{K}$ in common bean plants may have been due to the improvement of the $\mathrm{K}$ absorption mechanism or to the greater development of roots by microorganisms.

\section{Yield components and grain yield}

For yield components, the increase in the number of pods per plant (47.4\%) was highlighted in plants inoculated with Ab-V5, 1381+ BRM 32114 and BRM 32114 + BRM 32110, followed by BRM 32111, BRM $32114+\mathrm{T}-26,1381+\mathrm{AB}-\mathrm{V} 5$, $1381+$ BRM 32110 and $1301+$ BRM 32110 (Figure 3A). The increase in the number of grains per pod obtained in common bean plants inoculated with the isolate BRM 32112 was double compared to the control (Figure 3B). In relation to the increase in the mass of 100 grains (10.8\%), most treatments based on bioagents showed a beneficial effect, with emphasis on common bean plants inoculated with the isolate BRM 32114 and the combination BRM $32110+T-26$ (Figure 3C).

In this study, the bioagents that stood out to stimulate increased grain yield in common bean plants were $A b-V 5$, 1381+ BRM 32114 and BRM 32114 + BRM 32110 (Figure 3D). Common bean plants inoculated with bioagents that differed significantly from non-inoculated plants showed an average grain yield increase equal to $66.5 \%$. In crops, such as common bean, where higher grain yield are the most important goal, the main criteria for selecting bioagents are those that lead to greater grain yield.

These results of higher grain yield in the microorganisms treatments instead of no-treated plants, corroborate those found by Yadegari et al. (2008), who reported that treatment with rhizobacteria significantly increased the number of pods per plant, the number of grains per pod, mass of 100 grains, mass of grains per plant and mass of pods per plant, with the co-inoculation with Rhizobium and rhizobacteria showed a significant increase in common bean yield and yield components.

The study shows that the highlighted microorganisms were the isolated Ab-V5 (Azospirillum brasilense) and BRM 32112 (Pseudomonas sp.), had a positive influence of Azospirillum brasilense on stomatal conductance, transpiration, number of pods per pot, grain yield and $\mathrm{N}$ and content $\mathrm{P}$ in the shoots of common bean plants and Pseudomonas sp. in the number of grains per pot, grain yield and $\mathrm{N}$ and $\mathrm{P}$ content in the shoots of common bean plants. Bacteria of the genus Azospirillum sp. are able to promote plant growth through biosynthesis and release of amino acids, indoacetic acid, cytokinins, gibberellins and other polyamines, favoring root growth and, consequently, intensifying the absorption of water and nutrients by plants. In addition to fixing atmospheric nitrogen $\left(\mathrm{N}_{2}\right)$ through the biological nitrogen fixation process (Zeffa et
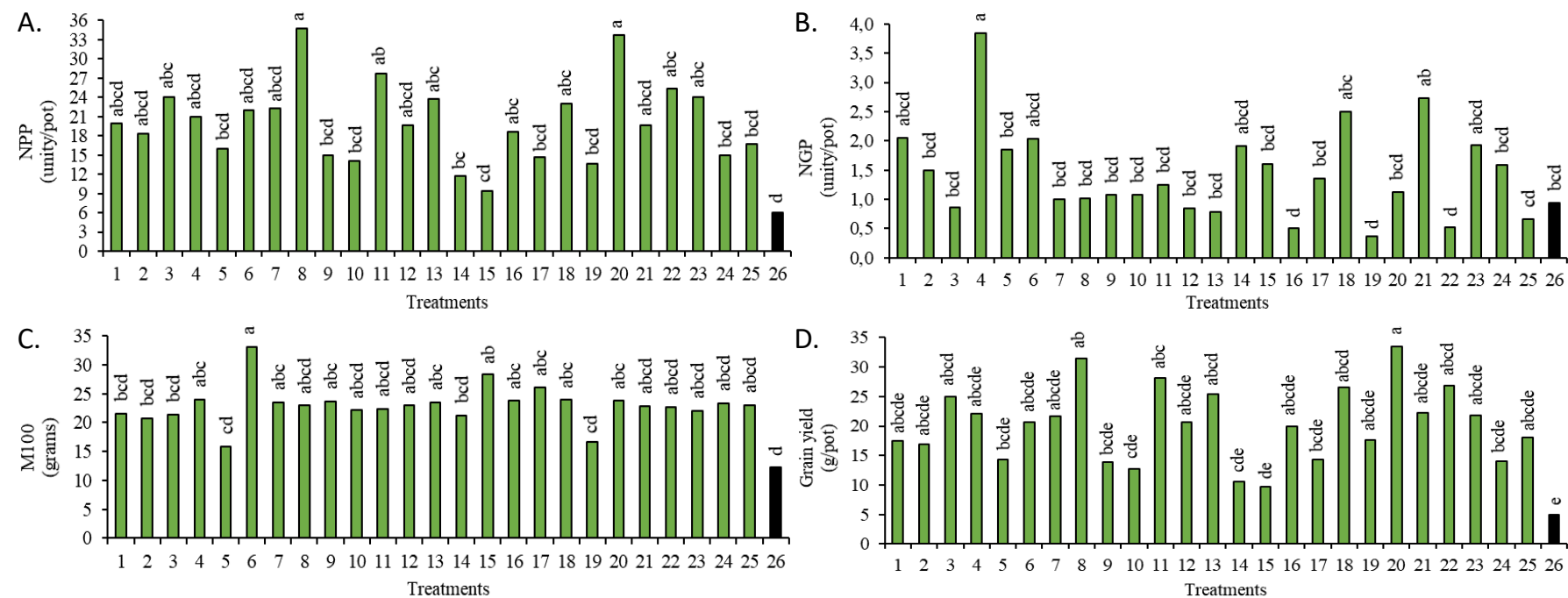

* Treatments followed by the same letter in columns do not differ from each other by the LSD test ( $p \geq 0.05)$. ** Treatments: (1) BRM 32109; (2) BRM 32110; (3) BRM 32111; (4) BRM 32112; (5) BRM 32113; (6) BRM 32114; (7) T-26; (8) Ab-V5; (9) 1381; (10) 1301; (11) 32114 + 32110; (12) 32114 + Ab-V5; (13) 32114 + T-26; (14) 32110 + Ab-V5; (15) 32110 + T-26 (16) Ab-V5 + T-26; (17) $1381+1301 ;$ (18) $1381+$ Ab-V5; (19) $1301+$ Ab-V5; (20) $1381+32114 ;(21) 1301+32114 ;(22) 1381+32110 ;(23) 1301+32110 ;(24) 1381+T-26 ;(25) 1301$ $+\mathrm{T}-26$; (26) control (without microorganism).

Figure 3. (A) Number of pods per pot; (B) Number of beans per pod; (C) Mass of 100 grains and (D) Grain yield common bean plants treated with multifunctional microorganisms, alone or in combination. 
al., 2019). The group of Pseudomonas sp. they promote plant growth either directly through phosphorus solubilization and production of siderophores or indirectly, with their ability to control plant diseases (Widnyana \& Javandira, 2016).

The combinations BRM $32114+\mathrm{T}-26$ (Serratia sp. + Trichoderma koningiopsis), BRM $1301+$ BRM 32110 (Bacillus sp. + Bacillus thunringiensis) and BRM $32114+$ BRM 32110 (Serratia sp. + Bacillus thunringiensis) are also featured in this study. These combinations positively influenced the number of pods per pot, grain yield and $\mathrm{N}$ content in the shoots. In addition, the BRM $32114+\mathrm{T}-26$ and BRM $1301+$ BRM 32110 combinations influenced the $P$ content in the root and the internal $\mathrm{CO}_{2}$ concentration, while the BRM $32114+\mathrm{BRM}$ 32110 influenced the $P$ content in the shoots of common bean plants.

The genus Serratia sp. associated with plants, promotes plant growth by various mechanisms, such as indolacetic acid production, nitrogen fixation, 1-aminocyclopropane1-carboxylate deaminase activity, phosphate solubilization, siderophores production and systemic induction host plant resistance (Martínez et al., 2018). Bacillus sp. can promote plant growth through the production of phosphatase and phosphorus solubilization and is also frequently used in biological control (Widnyana \& Javandira, 2016). Trichoderma sp. it is known to be efficient in biological control, but recently it has been identified as a promoter of plant growth through the production of phytohormones such as auxins, cytokinins, abscisic acid, gibberellins, among others (Guzmán et al., 2018).

\section{Principal component analysis}

Regarding the analysis of the main components, it was found that the variability of treatments (isolated and combined microorganisms) observed in gas exchange (photosynthesis, transpiratory rate, stomatal conductance, internal $\mathrm{CO}_{2}$ concentration and leaf temperature), in the yield components (number of pods per pot, number of grains per pot and mass of 100 grains) and in grain yield and nutrient accumulation ( $N$, $\mathrm{P}$ and $\mathrm{K}$ ), both in shoots and in the roots, was better explained by five main components (PCs), representing $72.26 \%$ of the data variation, that is, PC1 (22.08\%), PC2 (18.94\%), PC3 (14.86\%), PC4 (8.89\%) and PC5 (7.49) (Figure 4).

The factor map (biplot) shows groups of variables (arrows) indicating positive and negative correlations with each main component $(\mathrm{PC})$, with the length of the arrow indicating the magnitude of each response for each PC (Figure 4). PC1 was positively correlated with grain yield, number of pods per pot and stomatal conductance. On the other hand, PC2 was positively correlated with transpiration, stomatal conductance, internal $\mathrm{CO}_{2}$ concentration and leaf temperature. While PC3 was positively correlated with $\mathrm{N}$ and $\mathrm{P}$ in the shoots. PC4 was positively correlated with photosynthesis and $\mathrm{K}$ at the roots while PC5 correlated positively with $\mathrm{P}$ at the roots.

The variables of $K$ in the roots, grain yield, number of pods per pot and $K$ in the shoots $(69.6,66.3,65.7$, and $64.2 \%$, respectively) presented the greatest contribution to $\mathrm{PC}$. For $\mathrm{PC2}$, transpiration, stomatal conductance, internal $\mathrm{CO}_{2}$

\section{A. PCA1 x PCA2}
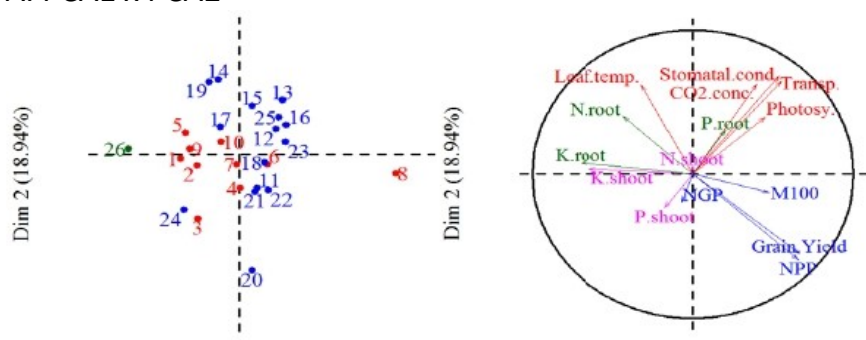

Dim $1(22.08 \%)$

B. PCA2 $\times$ PCA3
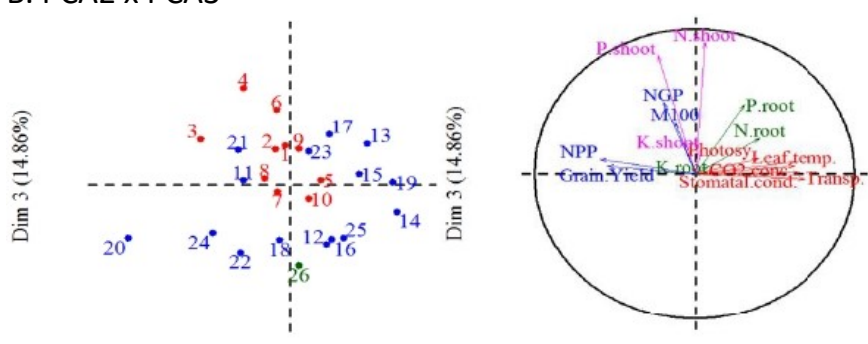

$\operatorname{Dim} 2(18.94 \%)$

$\operatorname{Dim} 2(18.94 \%)$

\section{PCA3 x PCA4}
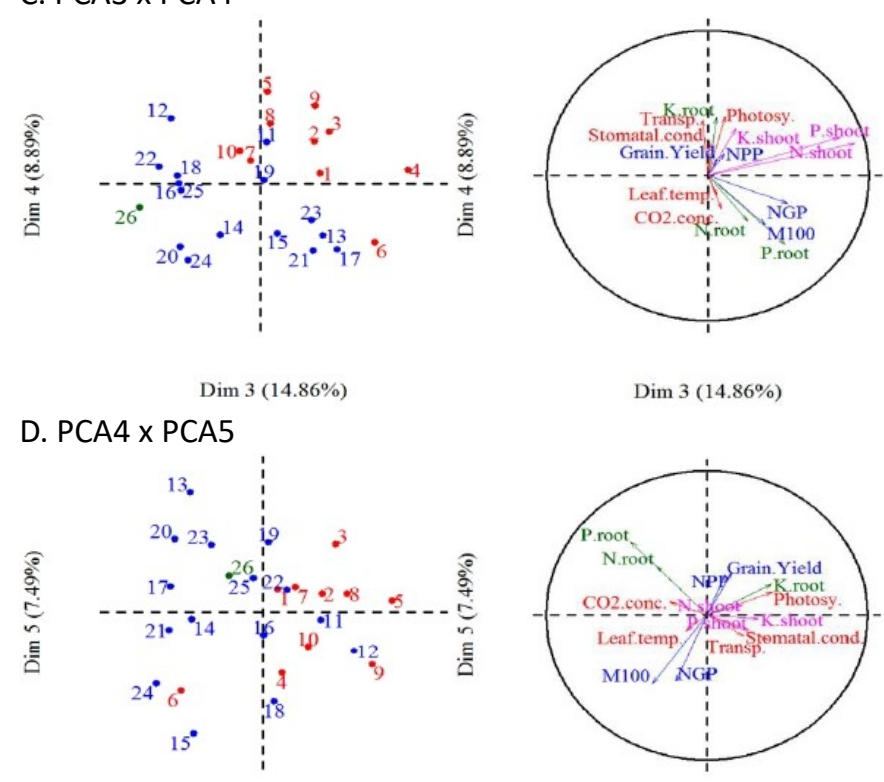

$\operatorname{Dim} 3(14.86 \%)$
Dim 4 (8.89\%)

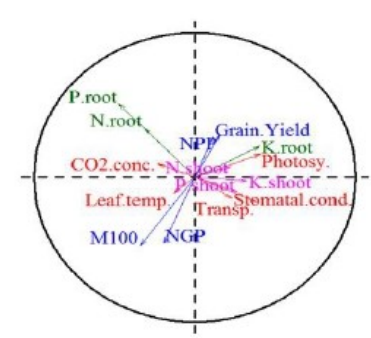

$\operatorname{Dim} 4(8.89 \%)$
Treatments isolates: (1) BRM 32109; (2) BRM 32110; (3) BRM 32111; (4) BRM 32112; (5) BRM 32113; (6) BRM 32114; (7) T-26; (8) Ab-V5; (9) 1381; (10) 1301 (red), in combination: (11) $32114+32110$; (12) 32114 + Ab-V5; (13) $32114+$ T-26; (14) $32110+$ Ab-V5; (15) $32110+\mathrm{T}-26$; (16) Ab-V5 + T-26; (17) $1381+1301 ;$ (18) $1381+\mathrm{Ab}-\mathrm{V} 5$; (19) $1301+\mathrm{Ab}-\mathrm{V} 5$; (20) $1381+32114$; (21) $1301+32114$; (22) $1381+32110$; (23) $1301+32110$; (24) $1381+$ T-26; (25) $1301+\mathrm{T}-26$ (blue); control (26) without microorganisms (green).

Figure 4. Principal component analysis (PCA) explaining correlations among variables and among 26 treatments with individual and combined microorganisms. Five main components (PCS) accounted for $72.26 \%$ of the data variation.

concentration and temperature $(67.9,64.6,62.4$, and $62.0 \%$, respectively) provided the greatest contribution. While for PC3, N and P in the shoots (91.0 and 81.7\%), for PC4, photosynthesis and $\mathrm{K}$ in the roots $(40.8$ and $40.4 \%)$ and for $\mathrm{PC5}, \mathrm{P}$ in the roots $(50.9 \%)$ were the variables that provided the greatest contributions. 
Based on the representational quality of treatments with isolated microorganisms and in combination for the variables analyzed, treatments 8 (Ab-V5) and 20 (1381 + BRM 32114) showed the greatest positive correlation for the mass of 100 grains and the number of pods per pot, respectively (Figure 4). The transpiration and stomatal conductance variables were positively correlated with treatments 14 and 19 (BRM $32110+A b-V 5$ and $1301+A b-V 5)$. The accumulation of $P$ in the shoots was positively correlated with treatment 4 (BRM 32112) and the accumulation of $P$ in the roots with treatment 6 (BRM 32114). Photosynthesis was positively correlated with treatment 5 (BRM 32113) and the accumulation of $P$ at the roots with treatment 13 (BRM $32114+$ T-26).

Therefore, it appears that multifunctional microorganisms significantly influenced the development of common bean plants such as gas exchange, yield components and grain yield and accumulation of macronutrients in the shoots and roots, and this resulted in more productive plants.

\section{Conclusions}

This study describes aspects of the effects of multifunctional microorganisms on common bean plants, providing a better understanding of the physiological and agronomic changes that occur in inoculated plants. Events such as gas exchange and macronutrient content in the shoots and roots were increased so that the plants could achieve increased yield components and grain yield.

The outstanding bioagents were Azospirillum brasilense (Ab-V5); Pseudomonas sp. (BRM 32112), in addition to the combinations Serratia sp. + Trichoderma koningiopsis (BRM 32114 + T-26), Bacillus sp. + Bacillus thunringiensis (1301 + BRM 32110) and Serratia sp. + Bacillus thunringiensis (BRM 32114 + BRM 32110). In addition, the results show an innovation in relation to a microorganism, however, complementary studies under field conditions are needed. The genus Trichoderma koningiopsis is important for the control of nematodes, but little studied as a growth promoter; however, the results show this genus as a highlight, providing an increase in gas exchange, accumulation of nutrients and components of yield and grain yield.

\section{Compliance with Ethical Standards}

Author contribution: Conceptualization: RCC, NAS, FMCC, LAC; Data curation: RCC, NAS, SJFA; Formal analysis: RCC, FLLM, SMA, PRAC; Funding acquisition: NAS, FMCC; Investigation: RCC, NAS, FMCC, LAC; Methodology: RCC, NAS, FMCC, LAC, SJFA; Project administration: RCC, NAS; Resources: NAS, FMCC, LAC; Software: No programs were developed; Supervision: NAS, FMCC, LAC; Validation: RCC, NAS, FMCC, LAC; Visualization: RCC, FLLM, SMA, NAS, FMCC, LAC; Writing - original draft: RCC, SMA, NAS; ML; Writing - review \& editing: RCC, NAS, FMCC, LAC.

Conflict of interest: The authors declare no conflict of interest.
Financing source: Empresa Brasileira de Pesquisa Agropecuária - Embrapa, Conselho Nacional de Desenvolvimento Científico e Tecnológico - CNPq (Process № 406507/2018-0) and Coordenação de Aperfeiçoamento de Pessoal de Nível Superior - Brasil (CAPES) - Finance Code 001.

\section{Literature Cited}

Ahemad, M.S.; Kibret, M. Mechanisms and applications of plant growth promoting rhizobacteria: current perspective. Journal of King Saud University - Science, v. 26, n.1, p.1-20, 2014. https:// doi.org/10.1016/j.jksus.2013.05.001.

Aquino, G.S.; Ventura, M.U.; Alexandrino, R.P.; Michelon, T.A.; Pescador, P.G.A.; Nicio, T.T.; Watanabe, V.S.; Diniz, T.G.; De Oliveira, A.L.M.; Hata, F.T. Plant-promoting rhizobacteria Methylobacterium komagatae increases crambe yields, root system and plant height. Industrial Crops and Products, v.121, n.1, p.277-281, 2018. https://doi.org/10.1016/j. indcrop.2018.05.020.

Braga Júnior, G.M.; Colonia, B.S.O.; Chagas, L.F.B.; Scheidt, G.N.; Miller, L.O.; Chagas Júnior, A.F. Soybean growth promotion and phosphate solubilization by Bacillus subtilis 467 strains in greenhouse. International Journal of Current Research, v.9, n.5, p.50914-50918, 2017. https://www.journalcra.com/sites/ default/files/issue-pdf/21977.pdf. 29 Jan. 2021.

Braga, R.M.; Dourado, M.N.; Araújo, W.L. Microbial interactions: ecology in a molecular perspective. Brazilian Journal of Microbiology, v.47, n.1, p.86-98, 2016. https://doi.org/10.1016/j. bjm.2016.10.005.

Carbonell, S.A.M.; Chiorato, A.F.; Bezerra, L.M.C.; Gonçalves, J.G.R.; Esteves, J.A.F.; Reis, L.L.B.; Carvalho, C.R.L.; Barros, V.L.N.P.; Freitas, R.S.; Ticelli, M.; Gallo, P.B. IAC 1850: High yielding carioca common bean cultivar. Crop Breeding and Applied Biotechnology, v.19, n.3, p.378-381, 2019. https://doi.org/10.1590/1984$70332019 v 19 n 3 c 53$.

Chaudhary, S.R.; Sindhu, SS. Growth stimulation of clusterbean (Cyamopsis tetragonoloba) by coinoculation with rhizosphere bacteria and Rhizobium. Legume Research, v.39, n.6, p.10031012, 2016. https://doi.org/10.18805/Ir.v0iOF.8605.

Companhia Nacional de Abastecimento - Conab. Acompanhamento safra brasileira de grãos. Brasília: Conab, 2021. 85p. (v.8 - Safra 2020/21, n. 4 - Quarto levantamento). https://static.poder360. com.br/2021/01/4-boletim-safra-2020-21-conab.pdf. 05 Aug. 2021.

Damam, M.; Kaloori, K.; Gaddam, B.; Kausar, R. Plant growth promoting substances (phytohormones) produced by rhizobacterial strains isolated from the rhizosphere of medicinal plants. International Journal of Pharmaceutical Sciences Review Research, v.37, n.1, p.130-136, 2016. https://globalresearchonline.net/ journalcontents/v37-1/24.pdf. 05 Feb. 2021.

Ekin, Z. Integrated use of humic acid and plant growth promoting rhizobacteria to ensure higher potato productivity in sustainable agriculture. Sustainability, v.11, n.12, e3174, 2019. https://doi. org/10.3390/su11123417. 
Ganascini, D.; Laureth, J.C.U.; Mendes, I.S.; Tokura, L.K.; Sutil, E.L.; De Villa, B.; Alovisi, A.M.T.; Caon, I.L.; Mercante, E.; Coelho, S.R.M. Analysis of the production chain of bean culture in Brazil. Journal of Agricultural Science, v.11, n.7, p.256-267, 2019. https://doi. org/10.5539/jas.v11n7p256.

Guzmán, P.G.; Troncoso, M.D.P.; Monfil, V.O.; Estrella, A.H. Trichoderma species: versatile plant symbionts. Phytopathology, v.109, n.1, p.6-16, 2018. https://doi.org/10.1094/PHYTO-07-180218-RVW.

Kado,C.J.; Heskett, M.G.Selectivemedia for isolation of Agrobacterium, Corynebacterium, Erwinia, Pseudomonas and Xanthomonas. Phytopathology, v.60, n.1, p.969-976, 1970. https://doi. org/10.1094/Phyto-60-969.

Korir, H.; Mungai, N.W.; Thuita, M.; Hamba, Y.; Masso, C. Coinoculation effect of rhizobia and plant growth promoting rhizobacteria on common bean growth in a low phosphorus soil. Frontiers in Plant Science, v.8, n.1, e00141, 2017. https://doi. org/10.3389/fpls.2017.00141.

Li, H.; Li, J.; Shen, Y.; Wang, J.; Zhou, D. Legume consumption and all-cause and cardiovascular disease mortality. BioMed Research International, v.2017, n.1, e8450618, 2017. https://doi. org/10.1155/2017/8450618.

Martínez, A.O.; Encina, C.; Tomckowiack, C.; Droppelmann, F.; Jara, R.; Maldonado, C.; Muñoz, O.; Fraile, P.G. Serratia strains isolated from the rhizosphere of raulí (Nothofagus alpina) in volcanic soils harbour PGPR mechanisms and promote raulí plantlet growth. Journal of Soil Science and Plant Nutrition. v.18, n.3, p.804-819, 2018. http://dx.doi.org/10.4067/s071895162018005002302.

Montesinos, S.B.; Diánez, F.; Gavira, A.M.; Gea, G.J.; Santos, M. Plant growth promotion and biocontrol of Pythium ultimum by saline tolerant Trichoderma isolates under salinity stress. Internatuonal Journal of Environmental Research Public Health, v.16, n.11, p.2053-2063, 2019. https://doi.org/10.3390/ ijerph16112053.

Nascente, A.S.; Filippi, M.C.C.; Lanna, A.C.; Souza, A.C.A.; Lobo, V.L.C.; Silva, G.B. Biomass, gas exchange, and nutrient contents in upland rice plants affected by application forms of microorganism growth promoters. Environmental Science and Pollution Research, v.24, n.3, p.2956-2964, 2017. https://doi.org/10.1007/s11356-0168013-2.

Oliveira, G.R.F.; Silva, M.S.; Marciano, T.Y.F.; Proença, S.L.; Sá, M.E. Initial bean growth as a function of seed vigor and inoculation with Bacillus subtilis. Brazilian Journal of Biosystems Engineering, v.10, n.4, p.439-448, 2016. https://doi.org/10.18011/ bioeng2016v10n4p439-448.
Paiter, A.; Freitas, G. IAA production and phosphate solubilization performed by native rhizobacteria in western Paraná. Agronomy Science and Biotechnology, v.5, n.2, p.70-76, 2019. https://doi. org/10.33158/ASB.2019v5i2p70.

Shi, Y.; Lou, K.; Li, C. Growth and photosynthetic efficiency promotion of sugar beet (Beta vulgaris L.) by endophytic bacteria. Photosynthesis Research, v.105, n.1, p.5-13, 2010. https://doi. org/10.1007/s11120-010-9547-7.

Silva, M.A.; Nascente, A.S.; Filippi, M.C.C.de; Lanna, A.C.; Silva, G.B. da; Silva, J.F.A e. Individual and combined growth-promoting microorganisms affect biomass production, gas exchange and nutrient content in soybean plants. Revista Caatinga, v.33, n.3, p.619-632, 2020. http://dx.doi.org/10.1590/198321252020v33n305rc.

Silva, P.A.; Cosme, V.S.; Rodrigues, K.C.B.; Detmann, K.S.C.; Leão, F.M.; Cunha, R.L.; Buselli, R.A.F.; Da Matta, F.M.; Pinheiro, H.A. Drought tolerance in two oil palm hybrids as related to adjustments in carbon metabolism and vegetative growth. Acta Physiologiae Plantarum, v.39, e58, 2017. https://doi.org/10.1007/s11738-017-2354-4.

Singh, M.; Singh, D.; Gupta, A.; Pandey, K.D. Plant growth promoting rhizobacteria: application in biofertilizers and biocontrol of phytopathogens. In: Singh, A.M.; Kumar, A.; Singh, P.K. PGPR amelioration in sustainable agriculture: food security environmental management. Duxford: Woodhead Publishing, 2019. Chap. 3, p.41-66. https://doi.org/10.1016/B978-0-12815879-1.00003-3.

Sureshbabu, K.; Amaresan, N.; Kumar, K. Amazing multiple function properties of plant growth promoting rhizobacteria in the rhizosphere soil. International Journal of Current Microbiology and Applied Science, v.5, n.2, p.661-683, 2016. https://doi. org/10.20546/ijcmas.2016.502.074.

Widnyana, K.; Javandira, C. Activities Pseudomonas spp. and Bacillus $\mathrm{sp}$. to stimulate germination and seedling growth of tomato plants. Agriculture and Agricultural Science Procedia, v.9, n.1, p.419-423, 2016. https://doi.org/10.1016/j.aaspro.2016.02.158.

Yadegari, M.; Rahmani, H.A.; Noormohammadi, G.; Ayneband, A. Evaluation of bean (Phaseolus vulgaris) seeds inoculation with Rhizobium phaseoli and plant growth promoting rhizobacteria on yield and yield components. Pakistan Journal of Biological Science, v.11, n.15, p.1935-1939, 2008. https://doi.org/10.3923/ pjbs.2008.1935.1939.

Zeffa, D.M.; Perini, L.J.; Silva, M.B.; de Sousa, N.V.; Scapim, C.A.; De Oliveira, A.L.M.; Amaral Júnior, A.T.A.; Gonçalves, L.S.A. Azospirillum brasilense promotes increases in growth and nitrogen use efficiency of maize genotypes. Plos One, v.14, n.4, e0215332, 2019. https://doi.org/10.1371/journal.pone.0215332. 